\title{
地震動の入カレベルが高架橋と電車線柱の 共振現象に与える影響評価
}

\author{
室野 剛隆 1 ・加藤 尚 $2 \cdot$ 豊岡 亮洋 3 \\ 1正会員（公財）鉄道総合技術研究所 構造物技術研究部（广185-8540 東京都国分寺市光町2-8-38） \\ E-mail:murono@rtri.or.jp \\ 2正会員 (公財) 鉄道総合技術研究所 構造物技術研究部（干185-8540 東京都国分寺市光町2-8-38) \\ E-mail:tkato@rtri.or.jp \\ 3正会員（公財）鉄道総合技術研究所 構造物技術研究部（干185-8540 東京都国分寺市光町2-8-38） \\ E-mail:akitoyo@rtri.or.jp.
}

\begin{abstract}
電車線柱は，高架橋の大規模地震に対する応答值を与条件として設計されている，高架橋の耐震設計は, 大規模な地震においては塑性化を許容し, 塑性後のじん性で安全性を確保するような設計体系である。ま た, 高架橋は塑性化すると振動周期が長周期化する傾向にある. 一方, 電車線柱と高架橋が共振すると電 車線柱の応答は著しく大きくなるため, 大規模地震で長周期化した高架橋の応答值を用いた現設計では, 電車線柱にとって安全側とは言い難い。そこで本研究では，地震動の特性や入力レベルが高架橋と電車線 柱の振動特性にどのような影響を与えるか検討を行った。 その結果, 中小規模の地震においても, 電車線 柱の応答が大規模地震よりも大きくなる可能性がある事が明らかになった。
\end{abstract}

Key Words : seismic response of power pole, interaction of power poles and viaducts, non-linear analysis

\section{1. はじめに}

地震による高架橋上の電車線柱の被害が着目され たのは, 1978 年の宮城県沖地震であった。その後も, 千葉県東方沖地震や北海道南西沖地震，兵庫県南部 地震など，電車線柱の被害は小規模であるが報告が されている。これらの電車線柱の被害は, 地震動の 大きさに依存するのはもちろんであるが，電車線柱 を支持する高架橋の地震応答特性に大きく影響を受 けることが，これまでの被害解析からも分かってい る。

そこで，著者らは，これまでに，高架橋上に建植 された電車線柱を対象に, 高架橋〜電車線柱の動的 相互作用の基本的な特性を把握するために，一連の 研究を実施してきた ${ }^{1)}$ 。これらの中で，著者らは， 1)構造物と電車線柱の周期比によって, 電車線柱の 応答が大きく変化し，特に両者の周期が一致すると 共振して，応答が著しく大きくなること，2)高架橋 の水平加速度により電車線柱が大きく振動させられ る以外に，高架橋がロッキングすることにより，電 車線柱が想定以上に振動すること，を指摘している. 1)の特性について, 特に, 電車線柱はその減衰定数 が小さいことから, 電車線柱の伝達関数は共振周期 付近で鋭く立ち上る形状となり，高架橋と電車線柱 の周期比でその応答が支配される。この現象につい ては, 現行の電車線柱の設計指針にも取り入れられ
ている ${ }^{2)}$.ただし，2)については，現行の電車線柱 の設計指針では考慮されていない.

ところで, 地震動の入力レベルが大きくなると高 架橋は塑性化するため, その振動周期も徐々に長周 期化する。土木構造物は，L2 地震に対して安全性 を確保していれば，それよりも小さな地震に対して は，基本的には安全性が保障されるが，上記のよう な特性に鑑みると, L2 地震のような大地震ではな く, 高架橋が塑性化しない中小規模の地震の方が, 電車線柱にとって厳しい状態になり得ることも想定 される。

そこで, 本研究では, 地震動の特性や入力レベル を変化させた場合, 高架橋と電車線柱の振動特性が どのように変化するのか定量的に把握した.

なお，2011年3月11日の東北地方太平洋沖地震で は，非常に多くの電車線柱が折損や傾斜をした ${ }^{3)}$. 本論文に関する検討は，この地震が発生する以前か ら実施されていた内容であり，今回の地震の被害原 因に言及したものではないことに注意して頂きたい. 今回の地震に対する電車線柱の被害原因に関しては, 別途，今後の検討が待たれるところである.

\section{2. 解析モデル}

本検討では，高架橋の地震応答特性が電車線柱へ 


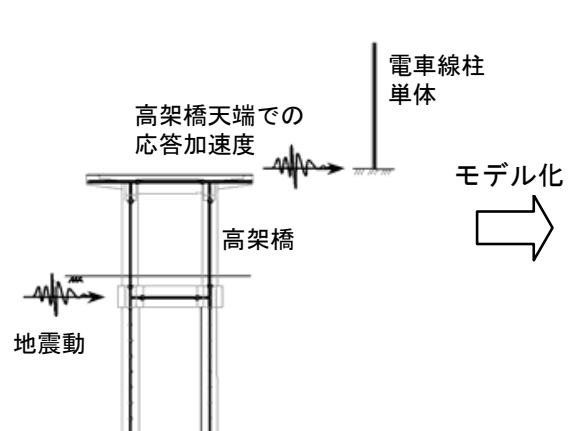

(a) 解析手法の概要

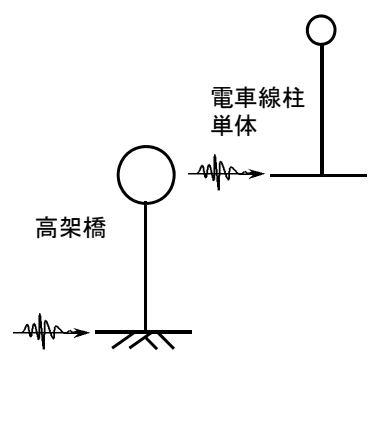

(b) 解析モデル

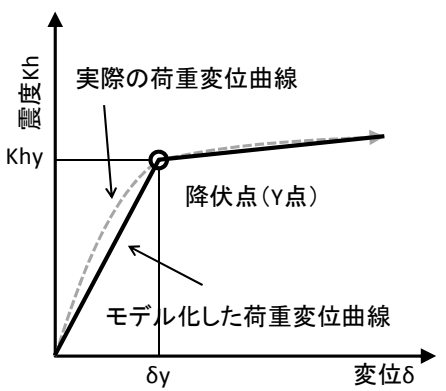

図-2 高架橋の骨格曲線

図-1 解析手法の概要と解析モデル

及ぼす影響について把握するため，電車線柱の耐震 設計 ${ }^{2)}$ と同様の手法にて解析を行った。すなわち, 図-1(a)に示すような地震時における高架橋天端の水 平応答加速度を算出し，その加速度を電車線柱下端 に入力する解析手法である. 今村ら ${ }^{1)}$ は, 前述した ように, 高架橋上の電車線柱の解析の際, 電車線柱 のロッキング運動等について報告しているが，本検 討では, 高架橋と電車線柱の基本的な振動特性を把 握することを目的としているため，これらの現象は 考慮しないものとする.

以上のことに鑑み，本検討における高架橋および 電車線柱のモデルについては, 図-1(b)に示すような 1自由度系にてモデル化を行った。また，高架橋に 用いる骨格曲線として, 高架橋の損傷状態を簡易に 評価するため, 図-2に示すような非線形性を考慮し たクラフモデルを, 電車線柱には線形モデルを用い た.

電車線柱の耐震設計において，設計条件として用 いられているのは, 高架橋の等価固有周期 $T_{e q}$, およ び高架橋の応答塑性率 $\mu$ であが，本検討では，高 架橋が有している耐震特性を把握しやすいよう, 高 架橋の降伏震度 $K_{h y}$ をパラメータとして解析を行っ た．表-1に，その解析ケース一覧を示す。ここで， 等価固有周期 $T_{e q}$ とは, 図-2に示すような高架橋の骨 格曲線において, 原点と降伏点（Y点）とを直線で 結ぶ割線剛性から求められる高架橋の固有周期であ り, 降伏震度 $K_{h y}$ と降伏変位 $\delta_{y}$ とを用いて, 式 (1) で表される4).

$$
T_{e q} \fallingdotseq 2.0 \sqrt{\delta_{y} / K_{h y}}
$$

また，電車線柱単体や電車線柱に付随する架線等の 重量を考慮し, 電車線柱の固有周期 $T_{p}$ を $0.2 \mathrm{sec} \sim$ 1.0secとして検討を行った。

減衰については，高架橋に5\%, 電車線柱に2\%の 減衰定数を与えた。

\section{3. 解析結果}

\section{（1）電車線柱と高架橋の基本振動特性}

まず，高架橋の振動特性が電車線柱に与える基本

\begin{tabular}{|c|c|c|c|}
\hline CASE & $\begin{array}{c}\text { 等価固有周期 } \\
T_{e q} \text { (sec) }\end{array}$ & 降伏震度 $K_{h y}$ & $\begin{array}{c}\text { 電車線柱の } \\
\text { 固有周期 } T_{p} \\
\text { (sec) }\end{array}$ \\
\hline CASE1 & \multirow{3}{*}{0.5} & 0.3 & \multirow{9}{*}{$\begin{array}{c}0.2 \\
\sim 1.0\end{array}$} \\
\hline CASE2 & & 0.5 & \\
\hline CASE3 & & 0.8 & \\
\hline CASE4 & \multirow{3}{*}{0.7} & 0.3 & \\
\hline CASE5 & & 0.5 & \\
\hline CASE6 & & 0.8 & \\
\hline CASE7 & \multirow{3}{*}{1.0} & 0.3 & \\
\hline CASE8 & & 0.5 & \\
\hline CASE9 & & 0.8 & \\
\hline
\end{tabular}

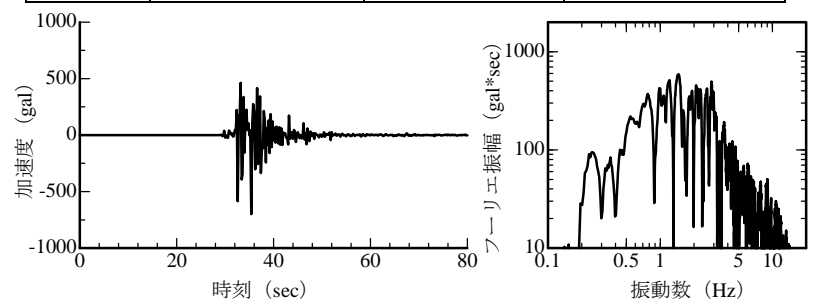

(a) 兵庫県南部地震（神戸海洋気象台）
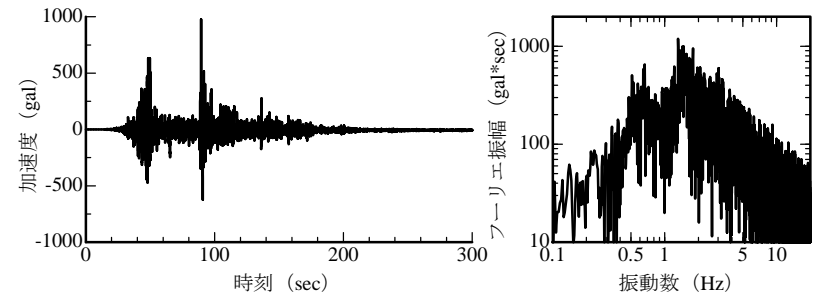

(b) 東北地方太平洋沖地震（K-NET 仙台）
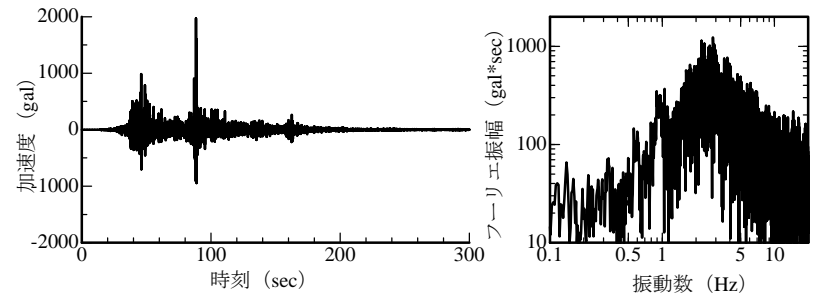

(c) 東北地方太平洋沖地震 (K-NET 塩籃)
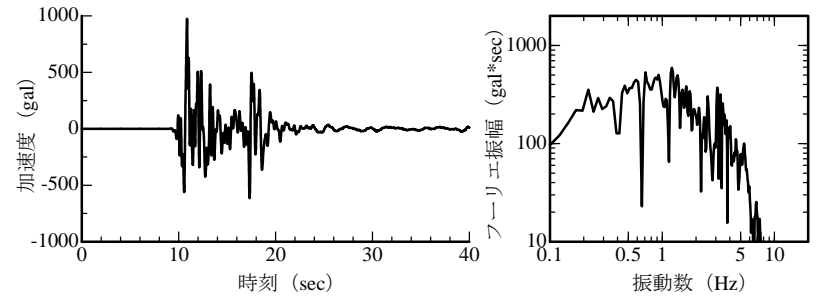

（d）耐震標準 L2 地震動スペクトル II 適合波（G3 地盤）

図-3 入力地震動 

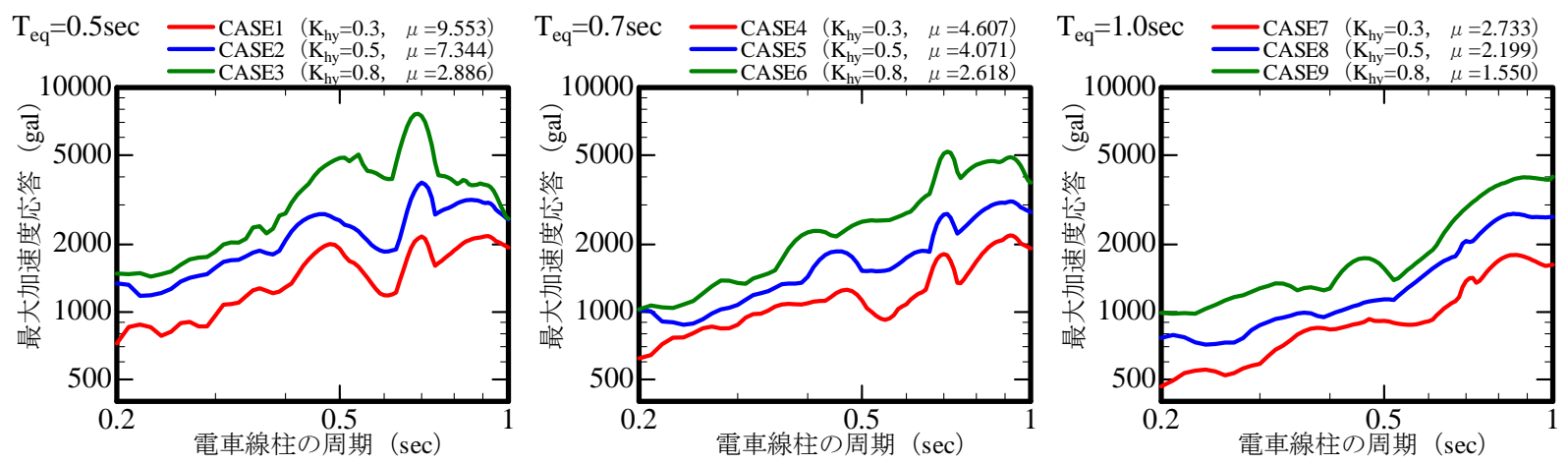

(a) 兵庫県南部地震（神戸海洋気象台）
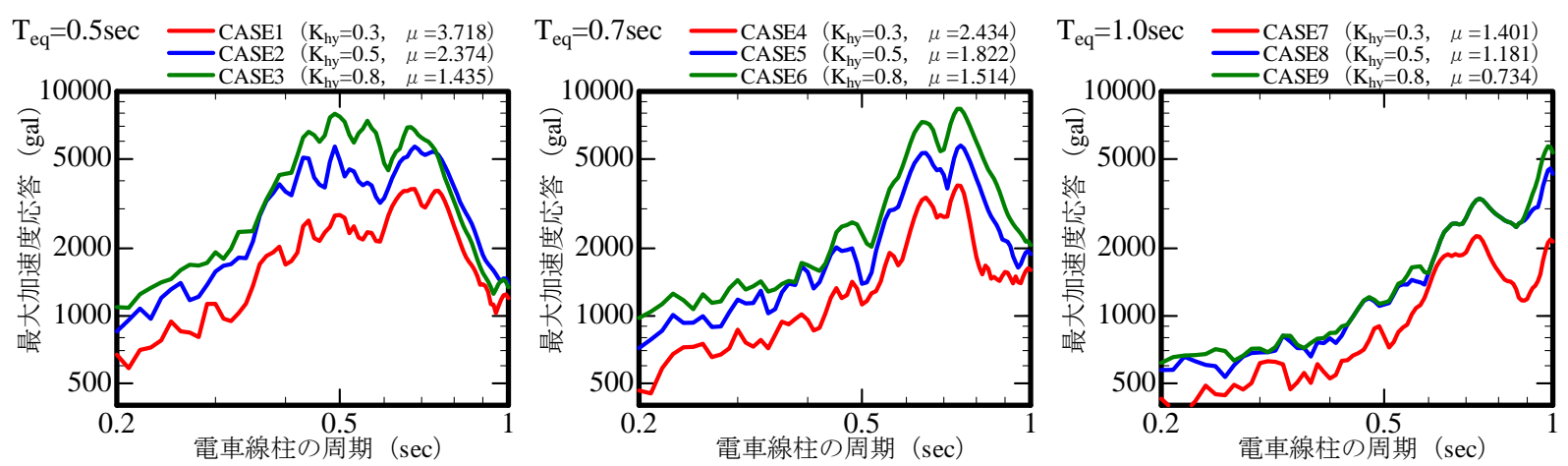

(b) 東北地方太平洋沖地震（K-NET 仙台）
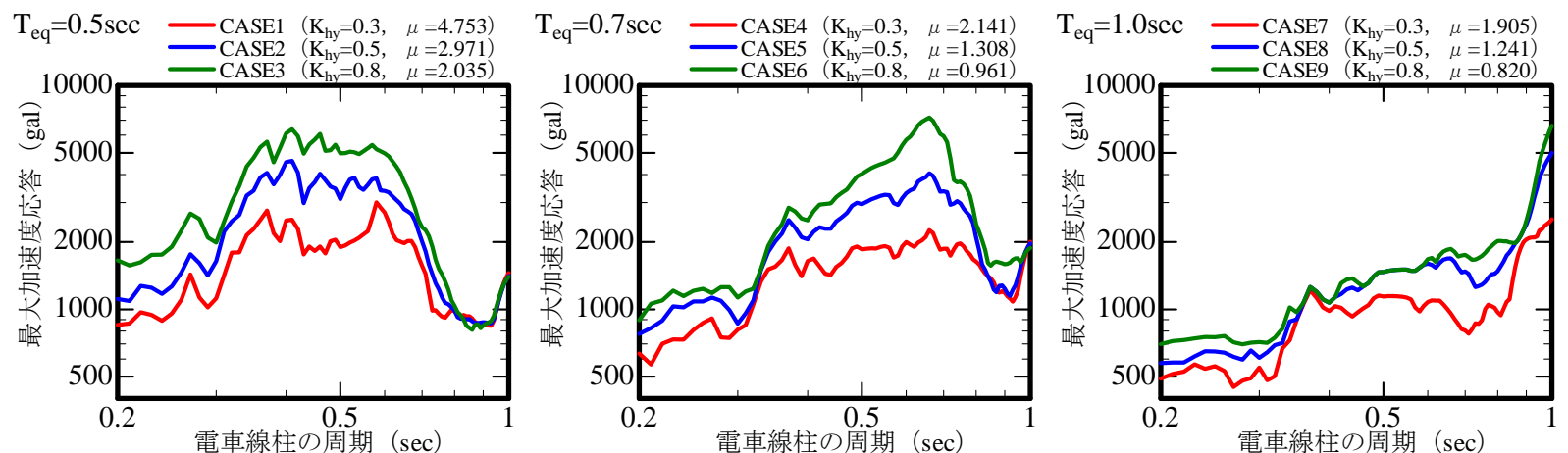

(c) 東北地方太平洋沖地震 (K-NET 塩䇫)
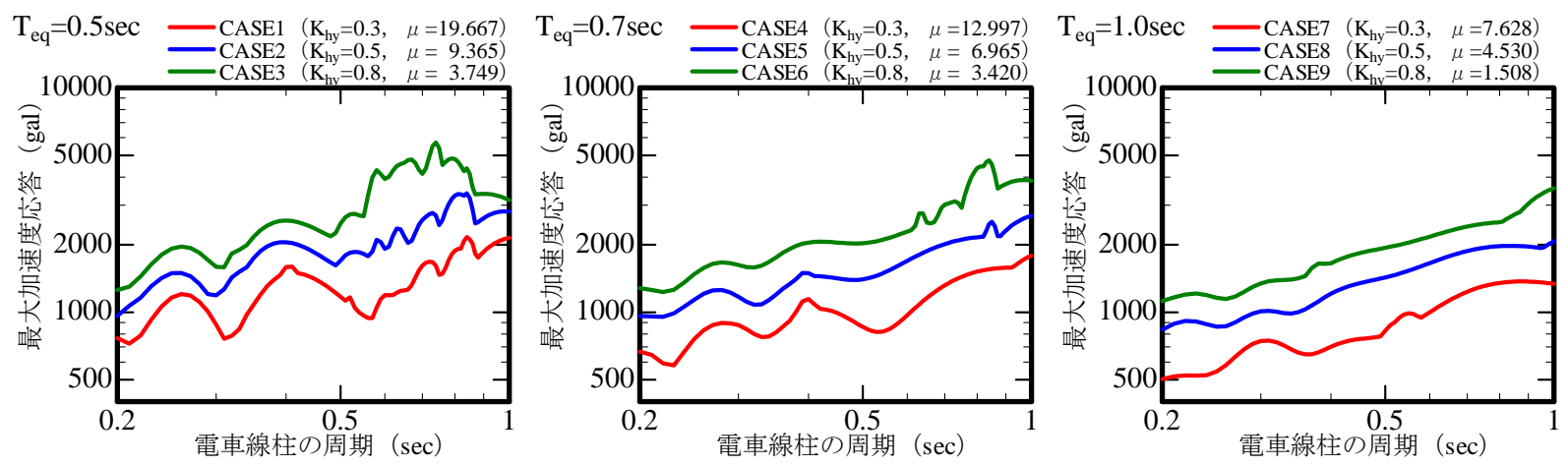

(d) 耐震標準 L2 地震動スペクトル II 適合波（G3 地盤）

図-4 電車線柱の最大加速度応答スペクトル

的な影響について把握するため，表-1に示した解析 ケースに対して，図-3に示すような性質の異なる 4 つの地震動（a）〜（d）を高架橋への入力地震動之 して解析を行った。 その解析結果を図-4 に示寸。こ こで, 各図は 4 つの地震動（a）〜（d）に対する各 解析ケースの電車線柱の応答結果であり, 横軸には 電車線柱の固有周期 $T_{p}$ を, 縦軸にその固有周期を
有する電車線柱の最大加速度応答の值を示している また，図-4(a)〜 (d)において，左図は高架橋の等価 固有周期 $T_{e q}$ が $0.5 \mathrm{sec} \quad$ (CASE1 CASE3），中図は $0.7 \mathrm{sec}$ （CASE4〜CASE6），右図は 1.0sec （CASE7 〜CASE9）の解析結果である. 凡例は, 高架橋の応 答塑性率 $\mu$ の值を示し, 塑性化の程度を表すものと する. 


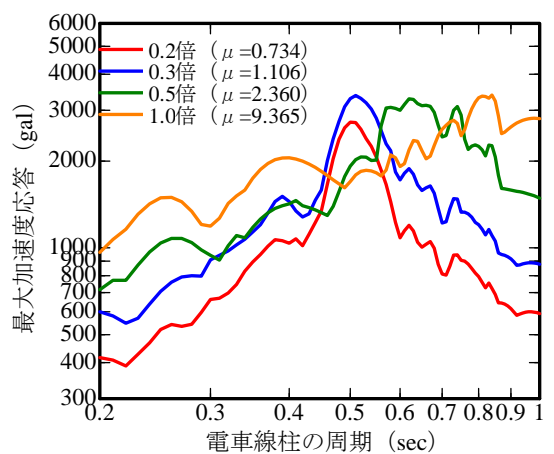

(a) CASE2( $\left.\mathrm{T}_{\mathrm{eq}}=0.5 \mathrm{sec}, \quad \mathrm{K}_{\mathrm{hy}}=0.5\right)$

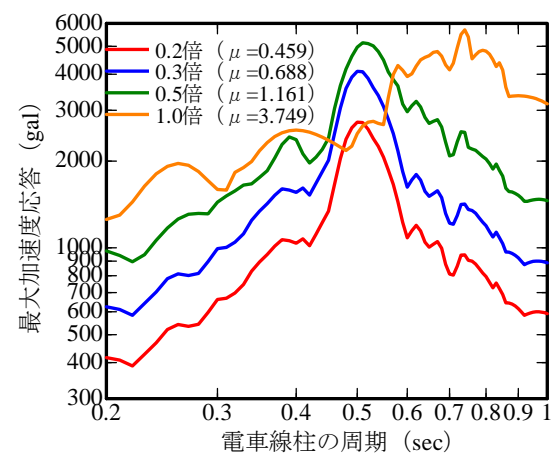

(b) $\operatorname{CASE3}\left(\mathrm{T}_{\mathrm{eq}}=0.5 \mathrm{sec}, \quad \mathrm{K}_{\mathrm{hy}}=0.8\right)$

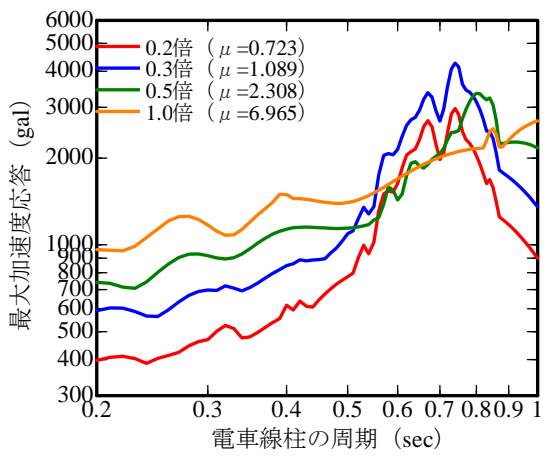

(c) $\operatorname{CASE5}\left(\mathrm{T}_{\mathrm{eq}}=0.7 \mathrm{sec}, \mathrm{K}_{\mathrm{hy}}=0.5\right)$

図-5 入力地震動の大きさによる電車線柱の加速度応答スペクトル比較

これらの図から，どの解析ケースにおいても，同 じ等価固有周期 $T_{e q}$ を有する高架橋において，降伏 震度 $K_{h y}$ が大きいほど電車線柱の最大加速度応答の 值が大きくなることが確認できる。これは，高架橋 が降伏すると，それ以上の加速度を電車線柱に伝え られなくなることが原因である。つまり，高架橋が 損傷しにくいほど, 電車線柱への入力地震動が大き くなるため, 電車線柱の加速度応答も大きくなる可 能性があるということがわかった.

また, 電車線柱の固有周期 $T_{p}$ と高架橋の等価固 有周期 $T_{\text {eq }}$ が近い值であると, 高架橋と電車線柱が 共振し, 加速度応答が大きくなることも明らかであ る.ただし, 正確には, 電車線柱の応答が最大とな る電車線柱の固有周期 $T_{p}$ は, 高架橋の等価固有周 期 $T_{e q}$ よりも多少大きい傾向にある.この傾向は, 高架橋の応答塑性率 $\mu$ が大きいほど顕著である. 例 えば、図-4(d)の CASE1〜CASE3 を比較すると，高 架橋の応答塑性率 $\mu$ が大きな CASE1 の方が, CASE3 よりも電車線柱の加速度応答の最大值が長 周期帯にあるのが確認できる。これは，ある大きさ 以上の地震動を高架橋へ入力寸ると, 高架橋が塑性 化・長周期化してしまい, 結果, その長周期化した 高架橋の周期と電車線柱の固有周期 $T_{p}$ が, 等価固 有周期 $T_{e q}$ より長い周期帯で共振したことが原因で ある。

\section{（2）高架橋の応答塑性率と電車線柱応答の関連性}

前章において, 地震動の特性に限らず，電車線柱 と高架橋が共振すると, その応答が大きくなること, そしてその特性は構造物の塑性化の程度に依存する 事がわかった。

そこで, 高架橋の損傷状態が電車線柱へ及ぼす影 響について把握するため, 同一地震動において, 加 速度の入力レベルを 0.2 倍, 0.3 倍, 0.5 倍, 1.0 倍と 変えて解析を行った. 入力寸る地震動は, 前章で用 いた地震動（d）の耐震標準の L2 地震動スペクトル II 適合波（G3 地盤）とした。ここで，地震動の入 カレベルによって, 高架橋の応答塑性率 $\mu$ が 1 未満

(弾性域) から 1 以上（塑性域）に及ぶ解析結果が 得られた CASE2, CASE3, 及び CASE5 を抜粋し, その結果を図-5に示寸. 図-5を見ると, 電車線柱の 応答特性として以下のことが分かる。
例えば，図-5 (a)を見ると，地震動の振幅倍率が $0.2 \sim 0.3$ 倍の場合には, 電車線柱の加速度応答スペ クトルは固有周期 $0.5 \mathrm{sec}$ のときにピークとなってい る. 特に, 地震動の振幅倍率が 0.3 倍の場合には, ピーク值は約 3,000gal に達している。また, 地震動 の振幅が増大寸ると, 電車線柱の加速度応答スペク トルが最大となる周期は長周期側に移動している. しかし，そのピーク值そのものは，概ね 3,000gal で 変化がない。この特性は, 図-5 (b)(c)でも共通して 見られる特性である。

まず，電車線柱の加速度応答スペクトルがピーク を示寸周期が，地震動の振幅とともに長周期側に移 行する理由について, 図-5 (a)を用いて考察する.

入力波の振幅倍率が $0.2 \sim 0.3$ 倍の場合には, 高架橋 の応答塑性率は $0.7 \sim 1.1$ の範囲であり, 高架橋は広 義の意味で弾性範囲であると言える。この場合には, 高架橋は等価固有周期 $0.5 \mathrm{sec}$ に近い周期で振動して いる。 その結果, 固有周期 $0.5 \mathrm{sec}$ の電車線柱が高架 橋と共振して, 最も大きな応答を示したものと解釈 できる.しかし，入力波の振幅が大きくなると，高 架橋の応答塑性率が 2.3 9.4 程度となっており, 塑 性化が進行している. その結果, 高架橋は等価固有 周期 $0.5 \mathrm{sec}$ よりも長い周期で振動することになり, 電車線柱が高架橋と共振する周期も, より長周期側 にシフトすることになったと解釈できる.

次に, 電車線柱の加速度応答のピーク值について 図-5 (a)を用いて考察する. 地震動の振幅倍率が 0.3 倍の場合, 周期が $0.5 \mathrm{sec}$ の電車線柱は弾性範囲で振 動している高架橋と共振して, その最大加速度は約 3,000(gal)に達している. しかし, 地震動の振幅をこ れ以上大きくしても, 高架橋は塑性化しているので 高架橋の応答加速度は頭打ちとなり, 高架橋の耐力 以上の加速度を電柱に伝えることができず，電車線 柱の応答も 3,000gal で頭打ちになったと考えられる. 図-5(b)では, 高架橋の降伏震度が図-5(a)よりも大き くなっており, 高架橋は大きな加速度を電車線柱に 伝えることができるので, 電車線柱の最大応答加速 度のピーク值は 5,000gal まで大きくなっているが， 定性的な特徵は図-5 (a) と一致している.

これらの結果から, 電車線柱の固有周期 $T_{p}$ が高 架橋の等価固有周期 $T_{e q}$ と共振するような周期帯な らば，高架橋が弾性域にとどまるような小さな地震 
動レベルの方が，大きな地震動よりも電車線柱の加 速度応答が大きくなる可能性があることが明らかに なった。また，その值は，高架橋の応答塑性率 $\mu$ が 1 程度を示すような地震動レベルにおいて，最も大 きな值を示す傾向にあることが確認できた.

また, 電車線柱の加速度応答の值に着目すると, 高架橋の降伏震度 $K_{h y}$ が 0.5 である CASE2, CASE5 よりも 0.8 である CASE3 の方が大きな值を示してい る事が確認できる。この事から, 電車線柱の加速度 応答の大きさは, 高架橋の降伏震度 $K_{h y}$ に依存して いると判断できる.

\section{4. まとめ}

本研究において，地震動の特性や入力レベルが高 架橋や電車線柱の振動特性に与える影響について検 討した。得られた結論を以下にまとめる.

(1) 高架橋が塑性化して固有周期が長周期化すると, 電車線柱と共振する周期帯も長周期化する.

(2) 電車線柱と高架橋が共振するような周期帯では, 入力地震動が高架橋の弾性域にとどまるような 小さなレベルの方が, 電車線柱にとっては厳し くなる可能性がある.
(3) 電車線柱の最大加速度応答の大きさは，高架橋 が塑性化する場合には, 高架橋の降伏震度 $K_{h y}$ に 依存する。

今後，本検討で明らかになった現象を踏まえて， 電車線柱の耐震設計手法の改良を目指し, 検討を行 いたいと考えている.

謝辞：本研究では，（独）防災科学技術研究所のKNETの観測記録を利用させていただきました。ここ に記して謝意を表します。

\section{EFFECT ASSESSMENT OF VIADUCT AND POLE RESONANCE FOR SEISMIC INPUT LEVEL}

\section{Yoshitaka MURONO, Takashi KATO and Akihiro TOYOOKA}

In the present design of power poles on viaducts of railway, seismic response is calculated using response of viaducts as input force. Since viaducts damaged during earthquake show plastic deformation behavior, natural period of tends to be longer and response may be reduced. Therefore, it is considered that input force given to power poles may be smaller during large earthquake. Additionally, power poles may show very large response with small earthquake if they resonate with viaducts.

In this paper, analytical study was conducted to know the effect of properties of seismic input waves on the seismic response of power poles on railway viaducts. Analytical results showed that seismic response of power poles may become very larger even if input seismic wave is small. 